\title{
SPECIFICITY OF HEALTH-RELATED BEHAVIOURS IN MIDDLE AND LATE ADULTHOOD
}

\section{SPECYFIKA ZACHOWAŃ ZDROWOTNYCH OSÓB W OKRESIE ŚREDNIE] I PÓŹNEJ DOROSŁOŚCI}

\author{
Magdalena Zadworna-Cieślak ${ }^{1(\mathrm{~A}, \mathrm{~B}, \mathrm{C}, \mathrm{D}, \mathrm{E}, \mathrm{F})}$, Nina Ogińska-Bulik ${ }^{1(\mathrm{~A}, \mathrm{~B})}$ \\ ${ }^{1}$ Institute of Psychology, University of Lodz, Poland
}

Authors' contribution Wkład autorów:

A. Study design/planning zaplanowanie badań B. Data collection/entry zebranie danych C. Data analysis/statistics dane - analiza i statystyki D. Data interpretation interpretacja danych E. Preparation of manuscript przygotowanie artykułu F. Literature analysis/search wyszukiwanie i analiza literatury G. Funds collection zebranie funduszy
Tables: 4

Figures: 0

References: 31

Submitted: 2016 Aug 06

Accepted: 2016 Oct 14

\section{Summary}

Background. Engaging in health-related behaviours is conditioned by many factors, including psychological and social ones. The extent to which it is done is also determined by gender and age. Health-related activity has specific and, presumably, different meanings at different stages of adulthood, which is associated with implementing by people roles and tasks typical of a given period of life. The study aimed to determine the specifics of the healthrelated behaviour in middle and late adulthood.

Material and methods. The research was conducted on a group of 285 people, including 154 persons in middle adulthood, i.e. 40-58 years old $(\mathrm{M}=45.05$, SD $=3.63)-77$ women and 77 men, and 130 in late adulthood, i.e. $61-88$ years old $(M=71.32 \mathrm{SD}=5.81)-70$ women and 60 men. The Health Behaviour Inventory by Z. Juczyński (2001) was used to measure health-related behaviours. The tool enabled determining the overall level of health-related behaviours and four selected categories, i.e. healthy eating habits, preventive behaviours, health-related practices and positive mental attitudes.

Results. The results indicate that women exhibit a higher level of health-related behaviours when compared to men (regardless of age), which is also evidenced in women in late adulthood when compared to those in middle adulthood. The extent of health-related behaviours in specific categories was also compared between groups. Functions of healthrelated behaviours were discussed with regard to their specifics of people's roles performed in society as well as the implementation of the development tasks typical of particular stages of adulthood.

Conclusions. It is recommended to adjust prevention and health promotion programmes to particular periods of human development and gender.

Keywords: health-related behaviours, middle adulthood, late adulthood

\section{Streszczenie}

Wprowadzenie. Podejmowanie zachowań zdrowotnych jest uwarunkowane wieloma czynnikami, w tym psychologicznymi i społecznymi. Różnią się one także w zależności od płci i wieku. Aktywność zdrowotna ma specyficzne i przypuszczalnie odmienne znaczenie na różnych etapach dorosłości, wiąże się z realizacją ról i zadań typowych dla danego okresu życia. Celem przeprowadzonych badań było ustalenie specyfiki zachowań zdrowotnych osób w okresie średniej i późnej dorosłości.

Materiał i metody. Badania przeprowadzono na grupie 285 osób, w tym przebadano 154 osób w wieku średniej dorosłości tj. 40-58 lat $(M=45,05 ; S D=3,63)$ - 77 kobiet i 77 mężczyzn oraz 130 osób w wieku późnej dorosłości tj. 61-88 lat $(\mathrm{M}=71,32 \mathrm{SD}=5,81)$ - 70 kobiet i 60 mężczyzn. Do pomiaru zachowań zdrowotnych zastosowano Inwentarz Zachowań Zdrowotnych (IZZ) autorstwa Z. Juczyńskiego (2001). Narzędzie to pozwala na ustalenie ogólnego wskaźnika zachowań zdrowotnych oraz nasilenia czterech kategorii zachowań prawidłowych nawyków żywieniowych, zachowań profilaktycznych, praktyk zdrowotnych oraz pozytywnych nastawień psychicznych.

Wyniki. Wyniki badań wskazują na wyższy poziom zachowań zdrowotnych w grupie kobiet w porównaniu z mężczyznami (niezależnie od wieku) oraz w grupie osób w okresie późnej dorosłości w porównaniu z osobami w wieku średniej dorosłości. Dokonano także porównania poziomu poszczególnych kategorii zachowań zdrowotnych pomiędzy grupami. Omówiono funkcje zachowań zdrowotnych i powiązanie ich specyfiki z pełnieniem ról społecznych i realizacją zadań rozwojowych ty powych dla poszczególnych etapów dorosłości.

Wnioski. Wskazane jest dostosowanie oddziaływań w zakresie profilaktyki i promocji zdrowia do okresu rozwojowego i płci.

Słowa kluczowe: zachowania zdrowotne, średnia dorosłość, późna dorosłość 


\section{Introduction}

Human's health largely depends on the chosen lifestyle. Strengthening, protecting and recovering health is done through various human activities. They are referred to as "health-related behaviours"; that is habitual and/or deliberate forms of human activities which are closely connected with health on the basis of objective knowledge and subjective beliefs [1].

Taking up health-related behaviours is conditioned by many factors. The role of psychosocial factors is a frequent subject of research in this area $[2,3,4,5]$. Health-related behaviours also differ depending on the sociodemographic characteristics of the people who follow them in particular gender and age. Research on the sociodemographic determinants of health-related adult behaviours does not always provide clear results - some highlight the role of age and gender as differentiating factors; others do not confirm such findings $[6,7,8,9,10$, 11]. Qualitative and quantitative differences between health-related activities of women and men of all ages can arise from the specific period of development and the implementation of tasks typical of the period, including health-related behaviours. However, relatively little attention has been paid to this issue so far. The problem of the changing dynamics of health behaviours in adults also appears to be poorly known.

Meanwhile, the interest of researchers in the period of those $40+$ is increasing. It might be because it is the time when the most common chronic diseases develop. It is also the critical moment for introducing prevention. There is consistent evidence of associations between mid-life behaviours and various late-life outcomes [12]. Healthy lifestyle and appropriate health-related behaviours can improve people's health condition and delay the occurrence of diseases $[13,14,15,16,17]$. This is important in the context of the rising number of older people in the general population in Poland and longer life-expectancy, which currently in Poland is, on average, 73.8 years for men and 81.6 for women. In relation to the year 1990, men live by 7.6 years longer and women by 6.4 years [18].

Developmental psychology divides the time after the age of 40 into middle and late adulthood. Most of the concepts of staging human development refer to the age to 55-60 years as middle age and to the time after 60 years - as late adulthood (ageing) $[19,20]$. Each of these stages provides individuals' with unique challenges, as described in theory by Havighurst [21] and Erikson [22]. Robert Havighurst's proposal refers to the individual development of human requirements and social expectations. In his view, implementation of development tasks conditions more than individuals' well-being also determines the degree to which they are accepted. The concept by Erik Erikson is part of the neopsychoanalitic approach and includes eight development stages defining specific psychosocial tasks. Each development stage comprises a continuum between opposite poles, one of which determines the desired direction of development and the other, its possible disturbance.

Human development is very malleable in middle adulthood, and its direction depends mainly on the individual and social factors. It is a period associated with the so-called midlife crisis, menopause and the "empty nest syndrome". As for the physical and general health, a middle-aged person experiences menopause, i.e. loss of their reproductive capacity [19]. Development tasks typical of this stage, as indicated by Havighurst [21] include supporting the development of growing children, achieving social and civil responsibility, maintaining professional efficiency, personal treatment of spouses and adapting to the physiological changes of middle age.

During this stage, individuals manifest their concern for the vocation and education of the next generation, they engage in professional and creative work, moving on the continuum between generativity and stagnation [22]. A diversity of different roles of men and women can be seen. Women are increasingly focused on family life raising children and caring for ageing parents, whereas men carry out more professional activities. Women seem to tend to take over control of health-related behaviours of their family members, e.g. tasks related to treatment, visits to doctors, preparing healthy meals.

The beginning of late adulthood is usually associated with retirement and the end of the professional activity. The pace of ageing in this period varies individually. This reduces the physical efficiency of the body, susceptibility to diseases is increased, and difficulties in treatment appear. As far as the biological dimension is concerned, catabolic processes prevail over the anabolic ones [20]. The period of late adulthood is full of many, so-called critical events [23]. They include the following: loss of health, lower fitness and physical attractiveness, loss of the loved ones, the prospect of death, retirement, loss of the social and economic status, the sense of usefulness and social prestige, or moving to either adult children or a nursing home. The development tasks of late adulthood, enumerated by Havighurst [21] include adapting to the decline in physical strength, retirement, reduced income and changing social roles, coming to terms with the death of a spouse, maintaining social relationships with people of own age and providing sufficient conditions for own existence.

Individuals attempt to reconcile their previous development stages and their identities, sum up their lives, which determines the new place on a continuum between integrity and despair. There appears wisdom; a virtue often worked out in this period of life [22]. The social context in which adult development takes place and the 
undertaken activities seem to be different for men and women.

Each stage of life becomes much more age-specific. Thus, it seems reasonable to include the development context in the analysis of people's lifestyles at given stages. The issue of the specificity of the health-related activity of people in the context of their development in middle and late adulthood and the typical roles for men and women were the objectives undertaken in the own research.

\section{Material and methods}

The study aimed to determine the specifics of health-related behaviours of people in middle and late adulthood. The authors sought answers to the following research questions:

- What is the extent of health-related behaviours of women and men aged $40+$ ?

- Are there any differences between the health-related behaviours of people in middle and late adulthood?

- Are there any differences between men and women in the health-related activity at various stages of development?

The study was conducted in a group of 284 people, including 154 middle-aged, i.e. 40-58 years old ( $M=45.05$, $\mathrm{SD}=3.63)-77$ women and 77 men, and 130 people in their late adulthood, i.e. $61-88$ years old $(\mathrm{M}=71.32 \mathrm{SD}=$ 5.81) - 70 women and 60 men.

The study was conducted in the city of Łódź. The study participants were chosen at random. The respondents classified as middle-aged were examined during gatherings in secondary schools where their children attended. The seniors represented the Third Age University and were examined in the institution. The research was voluntary and anonymous.

The Health Behaviour Inventory by Z. Juczyński [24] was applied for measuring the participants' healthrelated behaviours. The tool consists of 24 statements describing various types of health-related behaviours, the intensity of which is assessed on a scale from 1 ("almost never") to 5 ("almost always"). The overall rate of health-related behaviours was obtained after adding frequencies of following individual behaviours. This tool enables calculating the overall level of health-related behaviours and four categories of health-related behaviours, i.e.

- prevention behaviours (adherence to health recommendations and obtaining information about health and disease),

- proper eating habits (the type of the consumed food),

- health practices (habits associated with sleep, recreation and physical activity)

- positive mental attitudes (avoiding too strong emotions, tension and stress).

\section{Results}

In the first stage of statistical analyses, the whole group's level of health-related behaviours was determined $(\mathrm{M}=80.48, \mathrm{SD}=15.60)$. By referring to standard category values, the overall mean level of health-related behaviours was determined, which indicated the average level of particular variables. Mean scores for various categories of health-related behaviours were also similar to those obtained in the standards. Then, using the t-test, differences were determined between health-related behaviours of women and men in the whole group (Table 1).

Table 1. Health-related behaviours in women and men

\begin{tabular}{|c|c|c|c|c|c|}
\hline \multirow{2}{*}{$\begin{array}{c}\text { Variables - } \\
\text { Health-related behaviours }\end{array}$} & \multicolumn{2}{|c|}{ Women } & \multicolumn{2}{|c|}{ Men } & \multirow{2}{*}{$\begin{array}{l}t / \\
p\end{array}$} \\
\hline & M & SD & M & SD & \\
\hline General index of health behaviours & 83.50 & 15.28 & 77.24 & 15.33 & $\begin{array}{c}3.44 \\
* *\end{array}$ \\
\hline Proper eating habits & 20.88 & 4.95 & 18.02 & 4.98 & $\begin{array}{c}4.85 \\
* * *\end{array}$ \\
\hline Prevention behaviours & 20.62 & 4.98 & 18.66 & 4.92 & $\begin{array}{c}3.33 \\
* *\end{array}$ \\
\hline Positive mental attitudes & 21.39 & 4.31 & 21.02 & 4.28 & $\begin{array}{c}.73 \\
\text { ni }\end{array}$ \\
\hline Health practices & 20.63 & 4.41 & 19.54 & 4.36 & $\begin{array}{c}2.09 \\
*\end{array}$ \\
\hline
\end{tabular}

$\mathrm{M}$ - mean; SD - standard deviation; $\mathrm{t}$ - value of test $\mathrm{t}, \mathrm{p}$ - significance level

${ }^{* * *} \mathrm{p}<0.001,{ }^{* *} \mathrm{p}<0.01,{ }^{*} \mathrm{p}<0.05$ 
The mean results of health-related behaviours for men and women, when referred to the standard values, showed an average value (sten score of 5). Women, however, present a higher level of health-related activity than men - mainly in terms of healthy eating habits, preventive behaviours and health-related practices. These differences were not recorded only in the category of positive mental attitudes. The representatives of both sexes in a similar degree take care of their health in the psychological dimension, i.e. avoid stresses and tensions.

Then, differences between health-related behaviours of younger and older respondents (the dividing point being the age of 60) were calculated.

Table 2. Health-related behaviours in individuals in middle and late adulthood

\begin{tabular}{|c|c|c|c|c|c|}
\hline \multirow{2}{*}{$\begin{array}{c}\text { Variables - } \\
\text { Health-related behaviours }\end{array}$} & \multicolumn{2}{|c|}{ Middle adulthood } & \multicolumn{2}{|c|}{ Late adulthood } & \multirow{2}{*}{ t/ } \\
\hline & M & SD & $\mathbf{M}$ & SD & \\
\hline General index of health behaviours & 72.58 & 12.43 & 89.85 & 13.69 & $\begin{array}{c}-11.13 \\
* * *\end{array}$ \\
\hline Proper eating habits & 17.40 & 4.39 & 22.00 & 4.89 & $\begin{array}{c}-8.35 \\
* * *\end{array}$ \\
\hline Prevention behaviours & 17.25 & 4.27 & 22.55 & 4.33 & $\begin{array}{c}-10.35 \\
* * *\end{array}$ \\
\hline Positive mental attitudes & 19.90 & 4.22 & 22.77 & 3.86 & $\begin{array}{c}-5.93 \\
* * *\end{array}$ \\
\hline Health practices & 18.06 & 3.62 & 22.53 & 4.03 & $\begin{array}{c}-9.84 \\
* * *\end{array}$ \\
\hline
\end{tabular}

$\mathrm{M}$ - mean; SD - standard deviation; $\mathrm{t}$ - value of test $\mathrm{t}, \mathrm{p}$ - significance level

*** $\mathrm{p}<0.001,{ }^{* *} \mathrm{p}<0.01,{ }^{*} \mathrm{p}<0.05$

Both the overall level of health-related behaviours and the extent of the behaviours in each category record higher levels in elderly patients, and these differences are highly statistically significant. People in late adulthood, i.e. older than 60, represent better nutritional habits, better health-related practices, they take care more of their health prevention and their mental state as compared to younger respondents.

The differences between the elderly and the youth are maintained when gender is taken into account, i.e. older men ( $M=85.77$, SD 14.31) show a statistically significantly higher overall level of behaviours conducive to health than younger men $(M=70.60, S D=12.64 ; t=6.58, p<0.001)$. Also. women in late adulthood $(M=93.34, S D$ 12.18) take better care of their health than in the earlier stages of life $(M=74.87, S D=12.21 ; t=9.15 ; p<0.001)$. These differences were also observed in each category of the health-related behaviours.

Then, it was verified whether the established differences between men and women are also typical of the two age groups, i.e. middle and late adulthood (Tab. 3 and 4).

Table 3. Health-related behaviours in men and women in middle adulthood

\begin{tabular}{|c|c|c|c|c|c|}
\hline \multirow{2}{*}{$\begin{array}{c}\text { Variables - } \\
\text { Health-related behaviours }\end{array}$} & \multicolumn{2}{|c|}{ Women } & \multicolumn{2}{|c|}{ Men } & \multirow{2}{*}{$\begin{array}{l}\text { t/ } \\
\mathbf{p}\end{array}$} \\
\hline & M & SD & M & SD & \\
\hline General index of health behaviours & 74.87 & 12.21 & 70.60 & 12.64 & $\begin{array}{c}2.14 \\
*\end{array}$ \\
\hline Proper eating habits & 18.51 & 4.40 & 16.39 & 4.24 & $\begin{array}{c}3.05 \\
* *\end{array}$ \\
\hline Prevention behaviours & 18.10 & 4.27 & 16.51 & 4.26 & $\begin{array}{c}2.32 \\
*\end{array}$ \\
\hline Positive mental attitudes & 19.87 & 4.0 & 19.91 & 4.36 & $\begin{array}{c}.05 \\
\text { ni }\end{array}$ \\
\hline Health practices & 18.44 & 3.73 & 17.79 & 3.62 & $\begin{array}{c}1.08 \\
\text { ni }\end{array}$ \\
\hline
\end{tabular}

$\mathrm{M}$ - mean; SD - standard deviation; $\mathrm{t}$ - value of test $\mathrm{t}, \mathrm{p}$ - significance level

${ }^{* *} \mathrm{p}<0.01,{ }^{*} \mathrm{p}<0.05$

Gender affects the health activity of respondents between 40 and 60 years of age, but the level of diversity is not high, and the differences only apply to specific categories of behaviours. Thus, taking into account the overall level of health-related behaviours and healthy dietary habits as wells as preventive behaviours, it turned out that women take more care of their health than men, but the differences are not recorded in the categories of positive mental attitudes and everyday health-related practices. 
Table 4. Health-related behaviours in men and women in late adulthood

\begin{tabular}{|c|c|c|c|c|c|}
\hline \multirow{2}{*}{$\begin{array}{c}\text { Variables - } \\
\text { Health-related behaviours }\end{array}$} & \multicolumn{2}{|c|}{ Women } & \multicolumn{2}{|c|}{ Men } & \multirow{2}{*}{$\mathbf{t}$} \\
\hline & M & SD & $\mathbf{M}$ & SD & \\
\hline General index of health behaviours & 93.34 & 12.18 & 85.77 & 14.31 & $\begin{array}{c}3.26 \\
* *\end{array}$ \\
\hline Proper eating habits & 23.61 & 4.10 & 20.12 & 5.09 & $\begin{array}{l}4.33 \\
* * *\end{array}$ \\
\hline Prevention behaviours & 23.51 & 4.13 & 21.42 & 4.31 & $\begin{array}{c}2.82 \\
*\end{array}$ \\
\hline Positive mental attitudes & 23.04 & 3.95 & 22.45 & 3.76 & $\begin{array}{c}.87 \\
\text { ni }\end{array}$ \\
\hline Health practices & 23.17 & 3.77 & 21.78 & 4.21 & $\begin{array}{c}1.98 \\
\mathrm{ni}\end{array}$ \\
\hline
\end{tabular}

$\mathrm{M}$ - mean; SD - standard deviation; $\mathrm{t}$ - value of test $\mathrm{t}, \mathrm{p}$ - significance level

*** $\mathrm{p}<0.001,{ }^{* *} \mathrm{p}<0.01,{ }^{*} \mathrm{p}<0.05$

Among older respondents, over 60 years, greater attention to health is also noticeable in women, as compared with men, regarding the overall level of health-related behaviours and diet; it is lower though with regard to prevention. There were no differences between the genders concerning positive attitudes and daily mental health-related practices.

\section{Conclusions and discussion}

Having taken into account the entire surveyed group, the study shows that women over the age of 40 take up behaviours beneficial to health to a greater extent than men - they take care of the kind of food, adhering to health recommendations. To a lesser extent, these differences concern healthier habits, related to sleep and recreation. There were, however, no differences between both genders with regard to taking care of their mental health, i.e. positive mental attitude. The trend towards a more healthy lifestyle in women rather than men is visible both in middle and late adulthood. However, the rule does not apply to all types of health-related behaviours.

Differences in health-related behaviours between men and women can be explained by following gender stereotypes [25]. Women are expected pay greater attention to health, whereas men are supposed to limit the concern about health to promoting healthy activities or even risky for health behaviours. It turns out that women have the most significant impact on issues related to health and nutrition in families.

Many studies have confirmed the presence of higher levels of health-promoting behaviours in groups of women, as compared with men [11]. Differences between both genders can, however, apply to specific categories of behaviours. For example, studies conducted by Dolińska-Zygmunt [2] indicated that women preferred other health-related activities than men - alternative medicine, nutritional behaviours, avoiding stimulants, while men preferred physical activity.

However, in the case of seniors, i.e. people over the age of 60 , studies do not always indicate the role of gender in affecting health-related behaviours $[8,9,10]$. In this period, the health status deteriorates, which is expected to be a factor strongly influencing health-related activities in both men and women.

Age seems to be of great importance for the health-related activity. In the own study, people in late adulthood presented significantly more health-promoting behaviours than younger ones in middle adulthood. These differences were evident in both the overall level and in each category of behaviours.

As indicated by the data in the literature, the number of medical behaviours related to contacts with healthcare services increases with age - their aim is primarily treating diseases [26]. Studies show that people in late adulthood present more pro-health behaviours than those in early adulthood [6,27]. Previously, some other studies showed that older women far more often chose pro-health behaviours than those under the age of $60[28]$.

The processes of ageing force people to re-evaluate their priorities and take up other strengthening and health-supporting activities. In the case of an illness, they often take up deliberate, intentional health-related behaviours, which result from individuals' own conscious decisions. Deterioration of the health status creates favourable conditions to make a decision and change one's behaviours from adverse to health to those benefiting it. In the light of studies, the health status is a significant factor influencing health-related behaviours [11].

The study conducted by Huy et al. [29] showed that individuals with a positive attitude to ageing showed a significantly better health behaviour than those who identified themselves with a traditional, less positive standpoint on ageing. 
Some health-related behaviours can fade with age. For example, the studies conducted on the adult US citizens showed a decrease in physical activity with age [7]. It is possible, however, that one needs to take into account the specificities of particular behaviours and the development context typical of the particular stage of life to be able to observe the actual health-related behaviours. A decrease in the overall level of physical activity is not surprising, as it is more difficult to do exercise when people are older, but it can be replaced with other pro-health behaviours, related to the overall functioning. Changes in the health-related activity can occur, not so much with age, understood as the length of existence, but with going through various stages of development. Health-related activity at each of the stages can be connected with the challenges specific to that stage. Healthrelated behaviours can in fact be seen as part of a general lifestyle associated with the specificity of development tasks. The issue undoubtedly requires further research.

The following research and deliberations can lead to some conclusions related to health prevention and promotion. It would be advisable to adjust these effects to the development stage and gender [30,31]. It should be borne in mind that health-related behaviours can be enhanced at any age. Despite the health problems occurring after the age of 40 and in late adulthood, they are not necessarily associated with significantly reduced welfare. Despite experiencing physical health problems, individuals can experience an increase in terms of other dimensions of health (social, spiritual, emotional) and develop various forms of health-related behaviours. Furthermore, individual perceptions of ageing are an essential starting point for designing prevention programmes for older adults. Health-related activity should be integrated with ageing and the challenges that life brings at various stages.

\section{References:}

1. Heszen I, Sęk H. Psychologia zdrowia. Warszawa: PWN; 2012 (in Polish).

2. Dolińska-Zygmunt G. Podmiotowe uwarunkowania zachowań promujących zdrowie. Warszawa: Wydawnictwo Instytutu Psychologii PAN; 2000 (in Polish).

3. Zadworna-Cieślak M, Ogińska-Bulik N. Zachowania zdrowotne młodzieży - uwarunkowania podmiotowe i rodzinne. Warszawa: Difin; 2011 (in Polish).

4. Ziarko M. Zachowania zdrowotne młodych dorosłych - uwarunkowania psychologiczne. Poznań: Bogucki; 2006 (in Polish).

5. Geboers B, Reijneveld SA, Jansen CJ, de Winter AF. Health Literacy Is Associated With Health Behaviors and Social Factors Among Older Adults: Results from the LifeLines Cohort Study. J Health Commun 2016; 21: 45-53. https://doi.org/10.1080/10810730.2016.1201174

6. Dębska U, Guła-Kubiszewska H, Starościak W, Bielawska I. Zachowania zdrowotne osób w okresie wczesnej i późnej dorosłości - aspekt edukacyjny i behawioralny. Psychologia rozwojowa 2009; 14(3): 77-88 (in Polish).

7. Hawkins MS, Storti KL, Richardson CR, King WC, Strath S, Holleman RG, et al. Objectively measured physical activity of USA adults by sex, age, and racial/ethnic groups: a cross-sectional study. Int J Behav Nutr Phys Act. 2009; 6:31. https://doi.org/10.1186/1479-5868-6-31

8. Muszalik M, Zielińska-Więczkowska H, Kędziora-Kornatowska K, Kornatowski T. Ocena wybranych zachowań sprzyjających zdrowiu wśród osób starszych w oparciu o Inwentarz Zachowań Zdrowotnych Juczyńskiego w aspekcie czynników socjo-demograficznych (Assessment of selected health behavior among elderly people in Juczyński's Inventory of Health Behavior regarding socio-demographic factors). Probl Hig Epidemiol. 2013; 94(3): 509-513.

9. Ogińska-Bulik N, Zadworna-Cieślak M, Rogala E. Rola zasobów osobistych w podejmowaniu zachowań zdrowotnych przez osoby w wieku senioralnym. Probl Hig Epidemiol. 2015; 96(3): 570-577 (in Polish).

10. Sygit-Kowalkowska E. Zachowania zdrowotne osób w okresie późnej dorosłości - socjodemograficzne korelaty i różnice między środowiskami społecznymi. Annales Academiae Medicae Stetinensis, Roczniki Pomorskiej Akademii Medycznej w Szczecinie 2013; 59(1): 103-113 (in Polish).

11. Zadworna-Cieślak M, Ogińska-Bulik N. Zachowania zdrowotne osób w wieku senioralnym - rola optymizmu. Psychogeriatria Polska. 2013; 10(4): 145-156 (in Polish).

12. Lafortune L, Martin S, Kelly S, Kuhn I, Remes O, Cowan A, Brayne C. Behavioural Risk Factors in Mid-Life Associated with Successful Ageing, Disability, Dementia and Frailty in Later Life: A Rapid Systematic Review. PLoS One 2016; 4;11(2), https://doi.org/10.1371/journal.pone.0144405.

13. Ford J, Spallek M, Dobson A. Self-rated health and a healthy lifestyle are the most important predictors of survival in elderly women. Age Ageing 2008; 37(2): 194-200. https://doi.org/10.1093/ageing/afm171

14. Franklin N, Tate C. Lifestyle and successful aging: an overview. Am J Lifestyle Med. 2009; 3(1): 6-11. https://doi.org/10.1177/1559827608326125 
15. Artaud F, Dugravot A, Sabia S, Singh-Manoux A, Tzourio C, Elbaz A. Unhealthy behaviours and disability in older adults: three-City Dijon cohort study. BMJ 2013; 23; 347: f4240. https://doi.org/10.1136/bmj.f4240

16. Adams J, Stamp E, Nettle D, Milne EM, Jagger C. Anticipated Survival and Health Behaviours in Older English Adults: Cross Sectional and Longitudinal Analysis of the English Longitudinal Study of Ageing. PLoS ONE 2015; 10(3): 1-12. https://doi.org/10.1371/journal.pone.0118782

17. May AM, Struijk EA, Fransen HP, Onland-Moret NCh, de Wit GA, Boer JM. et al. The impact of a healthy lifestyle on Disability-Adjusted Life Years: a prospective cohort study. BMC Medicine 2015, 13(1): 1-9. https://doi.org/10.1186/s12916-015-0287-6

18. Trwanie życia w 2014 roku. Warszawa: GUS; 2015. [cited 2016 Aug 04]; Available from http://stat.gov.pl/ obszary-tematyczne/ludnosc/trwanie-zycia/trwanie-zycia-w-2014-r-,2,9.html (in Polish).

19. Olejnik M. Średnia dorosłość. In: Trempała J., editor. Psychologia rozwoju człowieka. Warszawa: PWN; 2015. p. 312-325 (in Polish).

20. Straś-Romanowska M. Późna dorosłość. In: Trempała J., editor. Psychologia rozwoju człowieka. Warszawa: PWN; 2015. p. 326-350 (in Polish).

21. Havighurst R. Developmental tasks and education. New York: Longman and Green; 1981.

22. Erickson E. Childhood and society. New York: W.W. Norton and Company; 1963.

23. Finogenow M, Zadworna-Cieślak M. Wydarzenia krytyczne w okresie późnej dorosłości. Przedsiębiorczość i zarządzanie, „Zarządzanie stresem”. 2013, 14(5), część I: 97-116 (in Polish).

24. Juczyński Z. Narzędzia pomiaru w promocji i psychologii zdrowia. Warszawa: Pracownia Testów Psychologicznych Polskiego Towarzystwa Psychologicznego; 2001 (in Polish).

25. Mandal E. Podmiotowe i interpersonalne konsekwencje stereotypów związanych z płcią. Katowice: Wydawnictwo Uniwersytetu Śląskiego; 2000 (in Polish).

26. Ostrowska A. Prozdrowotne style życia, Prom Zdr. 1997; 4(10-11): 7-24 (in Polish).

27. Walker SN, Volkan K, Sechrist KR, Pender NJ. Health-promoting life styles of older adults: comparisons with young and middle-aged adults, correlates and patterns. Adv Nurs Sci 1988; 11(1): 76-90.

28. Nowak MA, Troczyńska T, Forjasz J, Nowak L. Chosen aspects of lifestyles of physically active women aged 4559 and 60-74. Health Problems of Civilization. 2016; 10(3): 30-37. https://doi.org/10.5114/hpc.2016.61364

29. Huy C, Schneider S, Thiel A. Perceptions of aging and health behavior: determinants of a healthy diet in an older German population. J Nutr Health Aging 2010; 14(5): 381-5. https://doi.org/10.1007/s12603-010-0037-6

30. Peel N, McClure R, Bartlett H. Behavioral determinants of healthy aging. Am J Prev Med 2005; 28(3): 298304. https://doi.org/10.1016/j.amepre.2004.12.002

31. Albert SM, Freedman V. Public health and aging: Maximizing function and well-being. New York: Springer Publishing; 2010. 